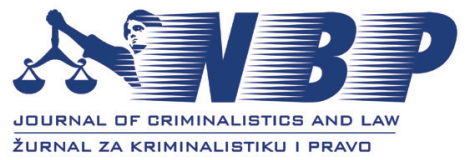

NBP 2021, Vol. 26, Issue 1, pp. 91-104 doi:10.5937/nabepo26-31514

History of policing

\title{
A Contribution to the Study of Rodolphe Archibald Reiss's Activities in the Kingdom of Serbs, Croats, and Slovenes (1919-1929)
}

\section{Srđan Milošević ${ }^{1}$ \\ Institute for Recent History of Serbia, Belgrade, Serbia}

Submitted: 2021-03-25 • Accepted: 2021-04-27 • Published: 2021-04-30

\begin{abstract}
In this paper two hitherto unknown letters related to the activity of Dr Archibald Reiss in the Kingdom of Serbs, Croats, and Slovenes (1919-1929) are presented and commented on. While Reiss's activities during WWI (1914-1918) are well documented and thoroughly researched, the knowledge about his engagement in the first post-war decade remains fairly scarce, due to the lack of sources. However, the available sources generally confirm that there was insurmountable tension in the relations between R. A. Reiss and the authorities of the Kingdom of Serbs, Croats, and Slovenes, almost from the very beginning of his "second term" in the service of the Belgrade government. The two Reiss's letters addressed to the Regent and King Aleksandar, published in this paper (one of which was hitherto unknown), clearly reveal the peculiar relationship between them. Another letter, rather a short diplomatic report, sheds some new light on the conditions of Reiss's return to the service of the government in Belgrade in 1919. The research clearly shows that Reiss occupied the position of the head of the Technical Service at the Department for Public Safety and also points out at his official reporting missions to Macedonia, on the request of the Minister of the Interior, in 1921 and 1922.
\end{abstract}

Keywords: Rodolphe Archibald Reiss (1875-1929), Aleksandar Karađorđević (1888-1934), Kingdom of Serbs, Croats, and Slovenes, Ministry of the Interior.

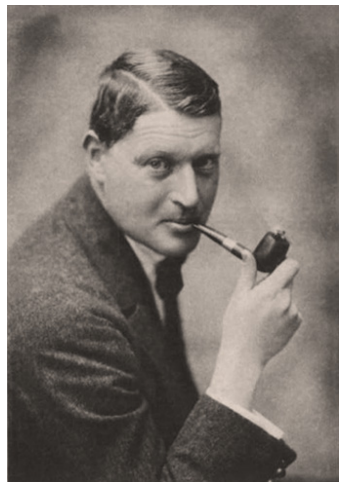

RODOLPHE ARCHIBALD REISS (1875-1929)
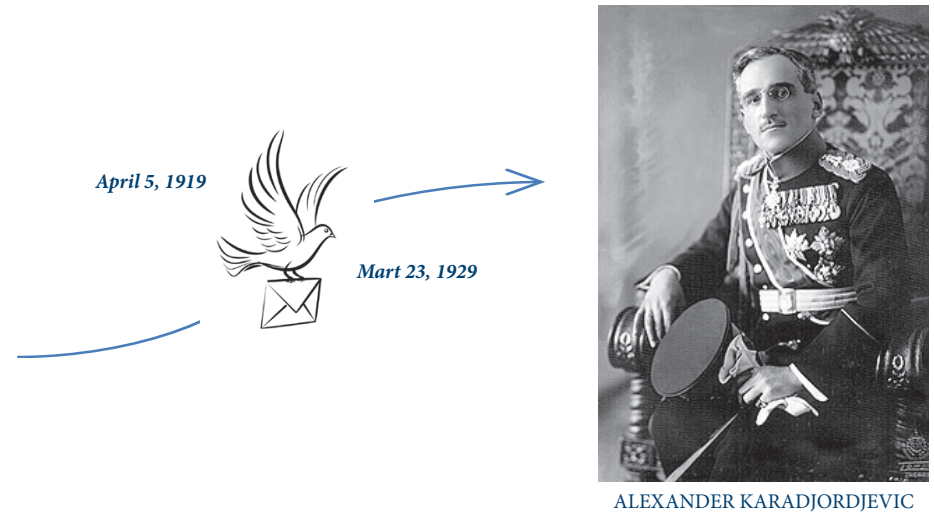

(1888-1934)

1 Corresponding author: srdjan.milosevic@inis.bg.ac.rs

Citation: Milošević, S. (2021). A contribution to the study of Rodolphe Archibald Reiss's Activities in the Kingdom of Serbs, Croats, and Slovenes (1919-1929). NBP. Nauka, bezbednost, policija, 26(1), 91- 


\section{INTRODUCTION}

The circumstances under which Dr Rudolf Archibald Reiss (1875-1929), a renowned criminologist and police expert, came to Serbia in 1914 are sufficiently known and scrutinized (Rajs, 2019a; Đorđević: 1930; Levental, 1993; Petrović, 2019). Having previously established professional ties with several persons coming from the Kingdom of Serbia (Mikić, 1968: 425), who were educated in Switzerland or engaged in the diplomatic service in that country, Reiss had also maintained a close friendship with some of them, which facilitated the establishment of contact with him in 1914. The immediate invitation to come to Serbia was delivered to Reiss on Stojan Protić's request by the Consul of the Kingdom of Serbia in Geneva, Nikola Petrović, of whom Reiss refers in his memoirs as "my old friend" (Rajs, 2019: 7-8). The reason for this invitation was the intention of Serbia's government to disclose to the European and world public what the scope and character of the atrocities inflicted on the population of Serbia by the occupying armies was.

Not surprisingly, the activities of R. A. Reiss in connection to the investigation of the crimes committed by the German, Austro-Hungarian and Bulgarian troops who had occupied the Kingdom of Serbia have been the subject of extensive and thorough analysis. This is unequivocally the most important and best documented aspect of Reiss's activity in Serbia and, later on, in the Kingdom of Serbs, Croats, and Slovenes (Kingdom of SCS), and, hence, most comprehensively researched. Reiss himself left exhaustive documentation about it, primarily seven extensive reports on crimes (Pršić, 2019), but also numerous articles in Swiss, French and Dutch journals and in memoirs (Levental, 1993: 45; Petrović, 2019: IX-XLV; Dimić, 2019: 376-377). The whole collection of the reports that Reiss wrote during the war and in the immediate post-war period has become the subject of historiographical research. Generally speaking, Reiss's war days are the focal point of the interest in both scholarship and publicists. Major scholarly works and some essays have been recently published in a collective volume (Rastović et al., 2019).

Compared to the war period of Reiss's life and career, the decade after the war remains somewhat blurred. The lack of the precise knowledge (apart from the major elements) about Reiss and his career in the last decade of his life came as a consequence of the most unfavourable circumstance that historians can imagine: Reiss's personal archive, kept by the Aupety family in Paris, had been devastated by the German occupiers (Levental, 1993: 189, fn. 30). In this paper, however, we are trying to establish, as accurately as possible, some facts regarding Reiss's arrival in Belgrade in 1919 and, further on, regarding the positions he assumed and tasks he performed in the Ministry of the Interior. We also present another Reiss's manuscript, his letter to King Aleksandar from March 1929 that contains a short retrospective of his short professional life in the Kingdom of SCS. 


\section{SHORT-LIVED ENGAGEMENT IN THE SERVICE OF THE GOVERNMENT OF THE KINGDOM OF SCS: ENTHUSIASM}

We know very little about Reiss's activity immediately after the engagement he had been entrusted with by the Serbian government (counselling of the Serbian/Yugoslav government at the Paris Peace Conference) came to an end in June 1919 (Mitrović, 2019: 54-55). At the end of 1919 we find Reiss in Belgrade, on a duty of the head of an ad hoc Section for Documenting War Crimes at the Ministry of Foreign Affairs (Levental, 1993: 169; Ristović, 2013: 119). But the question is: how did he come back to Belgrade?

Neither the circumstances of Reiss's return to Belgrade (after he had accomplished his task as an expert-counsellor for the mission of the Kingdom of Serbia at the Paris Peace Conference), nor the exact arrangement of his early employment in the Ministry of the Interior of the newly established state of the South Slaves have been clarified. We can say with certainty that Reiss was continuously expressing his willingness to continue his professional career in the Kingdom of SCS. In April 1919, while he was still a member of the Yugoslav delegation at the Paris Peace Conference, Reiss wrote a letter (full of disappointment and one might say - sadness) to the then Prince Regent Aleksandar Karađorđević. Although this letter has already been published by Zdenko Levental in Reiss's biography (Levental, 1992: 155-157), there is some value in republishing it in this paper, for the sake of the continuity of our account.

April 5, 1919

Your Royal Highness,

Before you left Paris, I have tried more than once to see you and to talk to you once again, because I felt that our cooperation had come to an end. Unfortunately, you were all too busy and I had no opportunity to thank you for all the friendship you showed me during the long years of the war. Today, my work ends here, and the delegation will soon return to Belgrade without me, because, unfortunately, the predictions from a few weeks ago have become a reality. Although I feel very sorry, I am not in a position to come to the country I fought for and which I learned to love as if it were my own.

You received me as a friend. Therefore, I need to be honest and tell you the whole truth. Here is what my situation looks like. That will explain to you why I am not going to return to your beautiful country. Before the war, my condition was great, both financially and morally. I was still relatively young, with an extraordinary career and I was making a lot of money. But money had no appeal to me. I made a modest fortune and lived comfortably. The war came and I believed that I should do what is already known to you. I left and spent everything, that is, I lost most of what I had. According to the information I received from a businessman who takes care of my interests, I have no more than 3,000 francs a year left, which is, of course, not enough to live on. Therefore, I have to work again and put my financial situation in order.

However, I could have done something if I had been given the position of minister in the mission that my country is about to open in Belgrade, a position that I should have

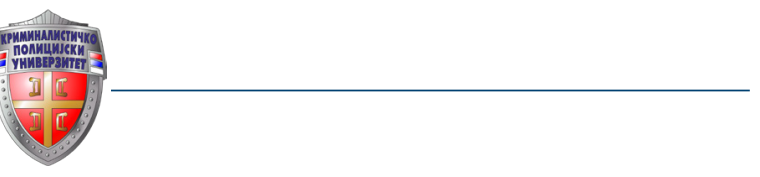


accepted at the request of the group that is the strongest in Switzerland today. However, for this plan to succeed, it was necessary that your government support it. That intervention, due to causes unknown to me, did not follow. You will have a Swiss embassy in Yugoslavia, but your old friend will not be the minister.

There was another duty in Serbia that could have enabled me to continue living in your country and, while ensuring my existence, to be at the same time useful to you. That was the position of the organizer of your police. You know my views in this area and You have fully endorsed them. The main idea of my project was to be allowed to create a police without politics. Today, however, it is clear to me that your politicians do not want the police without politics and therefore they do not want an uncompromised man for that matter. Therefore, it is not possible for me to accept that function in which I could have been useful to Your country.

These were two positions that were acceptable to me. Of course, your government wanted to offer me a chair at the University of Belgrade, but I cannot accept it. That would be a competition to the work I did in Lausanne, which served as an example for other countries to follow. I cannot compete with what I have created myself. Other places your government could have imagined would be merely sinecures, and my pride would never allow me to accept them. Therefore, there is no place for me in Serbia and I am forced to look for it elsewhere.

If, Your Majesty, someday you find out that I have accepted a position outside Serbia - and it will be in any case with a country friendly to yours - do not blame me and do not think that I have left and forgotten my friendship for Serbia. God knows how much I wanted to stay within the circle of those who became dear to me during those terrible years. Fate did not want me to be in a position to fulfil the role I wanted to play for the benefit of Your country and for myself. Only a cruel necessity will force me to accept a duty that I wanted to fulfil in your country.

While waiting for the future to come, I will continue to fulfil my duty here. When will I experience the joy and honour of seeing you again? I do not know. Since I couldn't do that in a personal conversation, I extend to you this way my sincere gratitude for the kindness and friendship that you showed to me. Despite everything, the years I spent in your army will remain the most beautiful of my entire life. I will always think of my Serbian friends and comrades and of You, their great leader.

You also sometimes think of a man who was often a jerk, but who was an honest and selfless friend. Please, Your Majesty, receive the expressions of my heartfelt and loyal feelings,

R. A. Reiss

According to Levental, the Regent "quickly and efficiently intervened in favour of his friend, so Reiss came back to Belgrade and took over two important functions there" (Levental, 1993: 167). But neither Levental, nor other scholars come out with precise date of Reiss's return to Belgrade. As it turns out, however, there was no "quick" and "effective" Aleksandar's intervention at all, because even in September 1919, Reiss's prospective engagement was still under the veil of uncertainty. As a 
matter of fact, it is quite possible that Reiss's eventual engagement in the Kingdom of SCS had nothing to do with the Regent's alleged intervention. Furthermore, Reiss does not seem to have received an answer from the Court.

However, after his task as an expert for the Yugoslav delegation in Paris had been accomplished, as we learn from one diplomatic letter (or rather dispatch), Reiss performed a secret mission on behalf of the French government in the "North Russia" (Archive of Yugoslavia [AY], n.d.). This is not quite surprising, given the fact that he obviously had the nerve for the clandestine missions. Namely, as he writes in his memoirs, back in 1914 he proposed to act as a counterspy in the service of the Allies, but this plan was abandoned by his engagement in Serbia (Reiss, 2019b). It is still unknown what the task was that the French government entrusted him with in the Soviet Union. Upon the completion of this secret mission, Reiss received an offer to enter the service of the Greek government. Pressed by the urgent need for employment, Reiss was at sea about his future career.

In a conversation Reiss had with a member of a Yugoslav diplomatic mission in Paris he once again had to repeat his offer to renew the engagement in Belgrade: his appeal to the Regent from April that year obviously did not produce any outcome. We learn that from a letter from 9 September 1919, written by an anonymous Serbian diplomatic official from Paris. The letter was addressed to the President of the Council of Ministers Ljubomir Davidović and urgently sent "by the first courier" to Belgrade. Hereby we quote the letter in extenso:

Prof. Reiss, of whom you are well aware, who spent almost the entire war period on our front and who did us so many favours with his professional and journalistic work (he was, among other things, an advisory member of our delegation at the Peace Conference), returned from North Russia a few days ago, where he was sent by the French government, entrusted with a confidential task. As the war is coming to an end and since he had left his chair at the University of Lausanne before he entered the ranks of our army on the Salonika front, he is, today, at the crossroads of his life. It seems that he would prefer to enter our service, if the Royal Government offered a position from which he could arrange our police service, which seems to have been discussed with one of your predecessors. At the same time, the Greek government (or rather Mr Venizelos himself) is offering him a very favourable position in the service of Greece.

He told me today that he would be forced to take the Greek offer into most serious consideration if our government abandoned the idea of using his knowledge and experience, and that he would do so with regret.

I ask you, Mr President, to take this matter into serious consideration, and thereby put me in a position to give Mr Prof. Reiss a definitive answer. On this occasion, I permit myself to emphasize that, in my humble opinion and deep conviction, it would be beneficial not only for our police service, but for our overall national cause, to preserve the cooperation of this well-known and respected public figure in Europe (AY, n.d.) (see Appendix A).

It is now evident that it was Davidovićs Cabinet that invited Reiss to Belgrade and offered him important positions firstly only temporarily within the Ministry of Foreign Affairs, and then within the Ministry of the Interior. Although such a possibil-

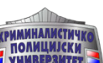


ity had been discussed with one of Davidović's predecessors (obviously Nikola Pašić or Stojan Protić), there were no concrete arrangements.

From the content of these letters and on the basis of their chronology, it is safe to conclude that from April to September 1919 there was an evident uncertainty regarding the prospects for Reiss's engagement in the service of the Kingdom SCS. It remains highly speculative whether Regent Aleksandar, who obviously kept silent for months, was consulted about the new arrangement and the forthcoming appointment of Dr Reiss to the office in the Ministry of Foreign Affairs and, later on - in the Ministry of the Interior.

In the late 1919 Reiss was appointed to the Commission for the Reorganization of the Police Service, which was formed by the Minister of the Interior. The commission completed its work by adopting the draft of an executive order regulating the structure of the police in Belgrade, which was enacted in August 1920 (KneževićLukić, 2019: 210-211). Reiss also assumed a position in the Ministry of the Interior as a contracted official (Ristović, 2013: 119-120), apparently after his engagement in the Section for Documentation of War Crimes ended. His work in the capacity of the high ranked officer in the Ministry of the Interior (1919-1922/23) still remains vague and fragmentary and only the main lines of his activities from that period have been drawn.

Firstly, Reiss was the founder and head of the Police School in Belgrade, established in 1921. But the school was virtually short-lived: in 1923 it was shut down (Đorđević, 1930: 8; Levental, 1993: 168-172; Krivokapić \& Ristović, 2002; Ristović, 2011; Krstić-Mistridželović, 2011; Krstić-Mistridželović, 2019: 30-34; KneževićLukić, 2019: 230-239). Secondly, he continued his work on the legislature related to the police service, but his proposal of the Law on the reorganization of the police service did not gain political support (Lazarević, 1930: 135; Krstić-Mistridželović, 2010: 284). Finally, the most important legacy of his engagement was the establishment of the Technical Service at the Department for Public Safety in 1920 (KneževićLukić, 2019: 196-198). The authors interested in this topic unanimously agree that Reiss had the crucial role in the establishing of this section (Lazarević, 1930: 133134.; Levental, 1993: 171-172; Knežević-Lukić, 2019: 197-198). However, there is no mentioning of his position within its structure. Thus the question remains: did Reiss occupy any official position in the Technical Service that he created?

This unit took over the tasks of the Identification section that, before this reorganization, had been headed by Reiss (Knežević-Lukić, 2019: 198). The scholars dealing with this topic, lacking the sources from this period, avoid identifying Reiss as the head of that section, although he virtually occupied that position. Vasa Lazarević wrote in his contribution to Spomenica: "As the head of our Technical Police, he noticeably contributed to the reorganization of this important branch of our profession" (Lazarević, 1930: 134). On the other hand, there is a report for the Minister of the Interior, composed by Reiss in 1921, that carries the signature "Head of the Section of technical service", which obviously was his official position at the time (Reiss, 1922). It is now safe to conclude that Reiss was personally in charge for that service, at least during 1921, but most likely from the establishment of the section until his withdrawal. 
Another new detail from Reiss's short engagement in the service of the Ministry of the Interior that we bring in this paper is his role as an official reporter on the situation in Macedonia (Southern Serbia of the time), where he travelled in August 1921 and in September/October 1922, the latter being among the last tasks that Reiss performed in his official capacity in the Ministry of the Interior. Altogether, Reiss spent almost two months in Macedonia in 1921/22.

Reiss journeyed to this area for the first time as a reporter for the Ministry of the Interior in August 1921, on the request of the Minister Svetozar Pribićević. On that occasion he visited predominantly western part of the province. He repeated his role of "field reporter" in September/October of the following year, probably also on the request of the Minister of the Interior, this time it was Kosta Timotijević. On this second trip Reiss visited larger number of towns and villages in the eastern part of Macedonia. He left detailed accounts of these missions in the form of extensive reports in which he presented a thorough analysis of demographic, economic, administrative, political and other issues of the region he visited (Reiss, 1921; Reiss, 1922). Between these two trips, Reiss travelled officially in Macedonia as a special envoy of the Minister of the Interior at least one more time. As we learn from Politika, this occurred in the beginning of July 1922 (Za bezbednost, 1922: 5). At the time he was investigating the crimes committed by the Bulgarian komitadjis on the territory of the Kingdom SCS. After he had returned from that short trip, on July 7, Reiss expressed bitter dissatisfaction because, as he argued, the issue of Bulgarian war criminals was taken lightly. According to the official data, there were over a hundred Bulgarian komitadjis who were active in the Kingdom of SCS at the time (Anketa g. Rajsa, 1922: 1).

In his reports, Reiss sharply criticized the organization of state services, the local administration and the way of governing in Macedonia. It is quite probable that these trips to Macedonia were the beginning of the end of Reiss's career as a civil servant in the Kingdom of SCS. In his "political testament" - as it is usually characterized - namely in the manuscript Listen, Serbs, Reiss unequivocally stated: "Your police officers were robbing the people and stealing their money, especially in southern Serbia (the underlining is ours - S. M). I reported this to your authorities, but these police officers - criminals, who were at the same time the activists of the political parties, were not punished, but it was me who had been severely insulted so that I was forced to resign" (Rajs, 2019b: 325). Indeed, shortly after his second official trip to Macedonia, Reiss retired from the public offices, never to assume another one, apart from the position of an expert in counterfeit money and documents employed by the National Bank (Đorđević, 1930: 8; Lazarević, 1930: 134).

Although it is well established that the general atmosphere characterizing the police administration of the time had made Reiss resign from his office, there is still disagreement among the sources and in the scholarship about when it actually happened. Scholarly works mainly skip that information. On the other hand, in some of them we find 1922 as the year of Reiss's resignation (Krstić-Mistridželović, 2011: 166), some authors mention both 1922 and 1923 in that context (Knežević-Lukić, 2019: 238, 277), while the Spomenica from 1930 indicates December of 1923 as the date of Reiss's withdrawal (Đorđević, 1930: 8). The same year is mentioned also by Sava Mikić (Mikić, 1968: 426). It is most likely that his resignation took place in 1923. 


\section{A DECADE LATER: DISILLUSIONMENT}

According to Reiss, the reason for his retirement lies in the intrigues and misunderstanding between him and some of the leading political figures of the time (Rajs, 2019b; Reiss, 1929). A somewhat milder version is offered by Vasa Lazarević who does, indeed, emphasize that Reiss was in disagreement with the "bureaucratic and outdated state administration", but when he was prevented from becoming chief of the Capital's public security service, due to the fact that he did not speak Serbian and thus could not get familiar with the positive legislation, he quit the job. It is true, however, that Reiss, as he admitted, never learned the Serbian language (Lalić, 1920), but it was not the main obstacle he was faced with in Belgrade. We can learn some details about Reiss's person, his own views on the abrupt cessation of his career, and about his thoughts on the decade he spent in the Kingdom of SCS, from a hitherto unpublished letter from March 1929. Reiss had sent this letter to King Aleksandar Karadjordjević just a few months before he died in his villa Dobro polje at the Topčider hill.

Belgrade, March 22, 1929

Majesty,

I read in the press that your Ministry of Interior is developing a new organic law on the police. On this occasion, I would like to inform you that in 1922, at the request of the then Minister of Interior, Mr Pribićević, I drafted a law on the police, which was a summary of my experiences and of what I saw during my career. Of course, the Minister, eager to destroy the one who gave everything to the Serbian nation at all costs, buried this project deeply, but other countries immediately asked about it. And, despite all their efforts, those who wanted my professional and scientific death in the Ministry of Interior did not succeed. Even today, my books represent an authority in the world of police, outside the Serbian police milieu, and they are still being translated today, even into Chinese.

I have no illusion that the people from the police, now when you have ordered that this important gear of public life is to be settled by a new law, will reconsider my previous work. But You, Your Majesty, You told me in the difficult moments of the war, "I am counting on you to help me in providing the Serbian state with a good police service". Therefore, I allow myself to ask you to go back to that project and read it. You will surely find it worth taking into consideration. It is quite possible that they made it disappear in the Ministry, but I have the original and it would make me glad to make a copy for you.

Do not think, Your Majesty, that I am writing all this to You in order to impose myself on you or to earn decorations and awards. After the war, the governments never gave them to me and today I am still doing quite well. But I have sacrificed everything that a man can sacrifice for Your country, which I love as my own, and I would also like the effort that I have invested for Your homeland not to be completely lost by someone's jealousy. Furthermore, I allow myself to believe that you have truly felt the affection and sincere friendship that I harbour towards you, and I would like to help my great royal friend in his difficult, but noble task. 
Forgive, Majesty, my liberty and look upon all this as yet another proof of deep devotion from your old R. A. Reiss (see Appendix B).

This letter remained unrevealed for decades, and even Reiss's most devoted biographer Zdenko Levental did not mention it. In his book, Levental claimed: "After the Paris letter from 1919, Aleksandar Karađorđević appears once again in a Reiss's writings, approximately ten years later. It was in his political testament, an explosive manifesto; a sort of last alarm entitled 'Listen, Serbs"' (Levental, 1993: 167).

The letter shows that Reiss did not give up his enlightening ideas of improving the conditions of the Yugoslav state and, in particular, the police service, in spite of all the malevolence and obstacles he encountered. However, the fact that he appealed to the king himself this time reveals both his belief that king Aleksandar might be incited to act constructively but also his despair. As far as we may know, Reiss did not receive an answer this time either. Be it by coincidence or not, Reiss made an accurate assumption: the project of the law he was entrusted with, just as he mentioned in his letter, remained "buried", never to be published. Yet, according to Vasa Lazarević, one of Reiss's friends and colleagues from the Ministry of Interior, the law passed in 1929 was only a slightly modified version of the project Reiss delivered in 1921 (Lazarević, 1930: 134).

\section{CONCLUSION}

The immediate circumstances of Reiss's renewed engagement in the Kingdom of SCS (who established the communication, who delivered an invitation to him, under what conditions, etc.) remain unknown.

By chance, at the beginning and at the end of Reiss's engagement in the Kingdom of SCS there are two letters: the first one - to Regent Aleksandar, and the second - to King Aleksandar. In both letters, from the two different life situations, Reiss addresses the one he knows to be the deciding factor in the country. In both situations it remains unclear what position Aleksandar took on the issues raised by Reiss. He probably ignored the sender on both occasions. For there certainly was something paternalistic in Reiss's approach, which could annoy the young, self-confident monarch. To him, Reiss's tone might have seemed like crossing the line and giving advice he had not asked for.

From the diplomatic dispatch sent from the mission of the Kingdom of SCS in Paris, we learn several details from Reiss's biography, the most interesting being the information about his secret mission to the USSR on behalf of the French government. This letter also unequivocally confirms that Reiss's engagement in the Kingdom of SCS was renewed during the cabinet of Ljubomir Davidović, in the end of 1919.

Two reports from his official trips to Macedonia could also shed more light on Reiss's biography, testifying to his two-month long activity of collecting information and impressions about the situation in this province in the summer of 1921 and autumn of 1922. The report from 1921 was signed by Reiss's official assignment - "the head of the Section of technical service", confirming that it was Reiss who ran this unit of the Department of Public Safety at the time.

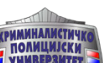


The sources that are in the focus of this paper are being published for the first time: they have been hitherto unnoticed by researchers and rested in the archival funds and collections. Their particular value is in the fact that archival and first hand sources about Reiss's life are very scarce. They are sometimes encountered while researching other topics. This circumstance increases the importance of the sources that would otherwise be of modest value or just an incidental footnote among a multitude of documents one might rightfully expect when it comes to important historical figures. In the case of Archibald Reiss, however, there is no such expected abundance of sources. Thus, each and every newly discovered first hand source, no matter how fragmentary it might be, sheds some new light on the biography of this highly relevant and intriguing person.

\section{ACKNOWLEDGMENTS}

This paper is realized within the Institute for Recent History of Serbia, which is funded by the Ministry of Education, Science and Technological Development of the Republic of Serbia, and on the basis of the agreement on realization and funding of the research work in 2021 no. 451-03-9/2021-14/200016 from February 5, 2021.

\section{REFERENCES}

Anketa g. Rajsa. (1922, July 8). Politika, 1.

Archive of Yugoslavia [AY]. (n.d.). Dispatch from the Legation of the Kingdom SCS in Paris to the President of the Council of Ministers (Legation of the Kingdom of Yugoslavia in France 388, Box 5, Foliation 233-234). Archive of Yugoslavia.

Dimić, LJ. D. (2019). Rodolf Arčibald Rajs (1875-1929): u potrazi za istinom, pravdom i pravom. Sociološki pregled, 54(2), 373-388.

Đorđević, S. M. (1930). Spomenica Dr Rajsu od srca k srcu: epopeja srpske, jugoslovenske i savezničke vojske 1914-1918. Jedinstvo.

Knežević-Lukić, N. (2019). Nastanak i razvoj naučno-tehničke policije u Srbiji (1904-1941). [PhD thesis, University in Belgrade]. https://nardus.mpn.gov.rs/handle/123456789/12141

Krivokapić V., \& Ristović S. (2002). Doprinos profesora Dr Rudolfa Arčibalda Rajsa izgradnji policijskog školstva u Srbiji. Bezbednost, 44 (1), 117-126.

Krstić-Mistridželović, I. (2010). Policija i unutrašnja uprava u Kraljevini SHS/Jugoslaviji (1918-1931). Bezbednost, 52(3), 282-297.

Krstić-Mistridželović, I. (2011). Archibald Reiss and the First Police School in Belgrade. In Ž. Nikač, S. Milašinović, D. Simović, \& G. Bošković (Eds.), International Scientific Conference "Archibald Reiss Days": Thematic conference proceedings of international significance (Vol. I, pp. 165-172). Academy of Criminalistics and Police Studies. 
Krstić-Mistridželović, I. (2019). Rodolf Arčibald Rajs: otac osnivač studija naučne policije. In I. Krstić-Mistridželović, R. Samardžić, N. Kenš, \& A. Rastović (Eds.), Rodolf Arčibald Rajs: Vizionar moderne policije (Knj. 3). Zavod za udžbenike i nastavna sredstva.

Lalić, D. (1920). Policija i država. Predavanje g. D-r Rajsa, profesora polic. tehnike na Lozanskom univerzitetu, držano 8. februara 1920. u Upravi grada Beograda. Policija, 7(3-4), 158-161.

Lazarević, V. (1930). Profesor Dr Rajs kao policajac i kriminalista. In S. Đorđević. Spomenica Dr Rajsu od srca k srcu: epopeja srpske, jugoslovenske i savezničke vojske 1914-1918 (pp. 133-135). Jedinstvo.

Levental, Z. (1993). R. A. Rajs: Švajcarac na Kajmakčalanu. Dečje novine; Den Orfelin.

Mikić, S. (1968). Dr Rudolf Aršibalf Rajs. In K. Todorović (Ed.), Kroz Albaniju 1915-1916: spomen knjiga. Prosveta.

Mitrović, A. (2019). Jugoslavija na konferenciji mira. Prometej; Radio televizija Srbije.

Petrović, M. F. (2019). Svedok istine o Srbiji 1914-1918. In M. Petrović (Ed.), Rodolf Arčibald Rajs: Ratni dopisi iz Srbije (Knj. 2). Zavod za udžbenike i nastavna sredstva.

Pršić, M. (Ed.). (2019). Rodolf Arčibald Rajs: O zločinima Austro-Ugaro-Bugaro-Nemaca u Srbiji 1914-1918 (Knj. 1). Zavod za udžbenike i nastavna sredstva.

Rajs, R. A. (2019a). Šta sam video i proživeo u velikim danima. In M. Pršić (Ed.), Rodolf Arčibald Rajs: O Srbiji i Srbima (Knj. 4). Zavod za udžbenike i nastavna sredstva.

Rajs, R. A. (2019b). Čujte, Srbi. In M. Pršić (Ed.), Rodolf Arčibald Rajs: O Srbiji $i$ Srbima (Knj. 4). Zavod za udžbenike i nastavna sredstva.

Rastović, A., Krstić Mistridželović, I., \& Samardžić, R. (Eds.). (2019). Rodolf Arčibald Rajs: Srbi o Rajsu (Knj. 5). Zavod za udžbenike i nastavna sredstva.

Reiss, R. A. (1921, September). [Report to the Minister of the Interior]. Archive of Yugoslavia (Collection of Vojislav Jovanović Marambo 335, Box 19, Foliation 633640), Belgrade, Serbia.

Reiss, R. A. (1922, November). [Report to the Minister of the Interior]. Archive of Yugoslavia (Collection of Vojislav Jovanović Marambo 335, Box 19, Folder 641673), Belgrade, Serbia.

Reiss, R. A. (1929). [Letter to King Aleksandar]. Archive of Yugoslavia (Collection of Vojislav Jovanović Marambo 335, Box 6, Folder 2), Belgrade, Serbia.

Ristović, S. (2011). Establishing police education in Serbia and contribution of Archibald Reiss. In Ž. Nikač, S. Milašinović, D. Simović, \& G. Bošković (Eds.), International Scientific Conference "Archibald Reiss Days": Thematic conference proceedings of international significance (Vol. I, pp. 173-179). Academy of Criminalistics and Police Studies.

Ristović, S. (2013). Rudolf Arčibald Rajs u Beogradu: reformator srpske policije. Limes Plus, 10(2), 115-126.

Za bezbednost na jugu. (1922, July 5). Politika, 1.

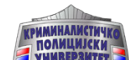




\section{APPENDIX A}

A letter to the President of the Council of Ministers of the Kingdom of Serbs, Croats and Slovenes from diplomatic mission in Paris, September 9, 1919

Poznati Vam prof. Rajs, koji je proveo na našem frontu gotovo sve vreme rata, i koji nam je svojim stručnjačkim i publicističkim radom učinio toliko usluga (bio je pored ostaloga i savetodavni član naše delegacije na mirovnoj konferenciji) vratio se pre neki dan iz Sev. Rusije kamo ga je bila poslala francuska vlada s jednom poverljivom zadaćom. Kako se rat završuje, a on je svoju katedru na sveučilištu u Lozani napustio kad je stupio u našu vojsku na Solunski front, on se danas nalazi na raskrsnici života. Izgleda da bi najradije stupio u našu službu, ako bi mu Kr. Vlada ponudila položaj s koga bi mogao urediti našu polic[ijsku] službu, o čemu kao da je bilo govora sjednim od Vaših prethodnika. U isto vreme njemu nudi grčka vlada (ili još bolje lično g[ospodin] Venizelos) vrlo povoljan položaj u službi Grčke.

On mi je izjavio danas da je prinuden uzeti u najozbiljnije razmatranje grčku ponudu ako je naša vlada napustila misao koristiti se njegovim znanjem $i$ iskustvom, $i$ ako bi to učinio sa žaljenjem.

Molim Vas G[ospodine] Pred[sedniče] da ovu stvar uzmete u ozbiljno razmatranje, te me po tom stavite u mogućnost dati gosp[odinu] prof[esoru] Rajsu definitivan odgovor. Tim povodom uzimam slobodu napomenuti, da bi po mome skromnom mišljenju $i$ dubokom uverenju bilo korisno ne samo za našu polic[ijsku] struku nego i za našu opštu narodnu stvar, sačuvati $i$ na dalje za nas saradnju ovog poznatog $i$ u Evropi uvaženog javnog radnika.

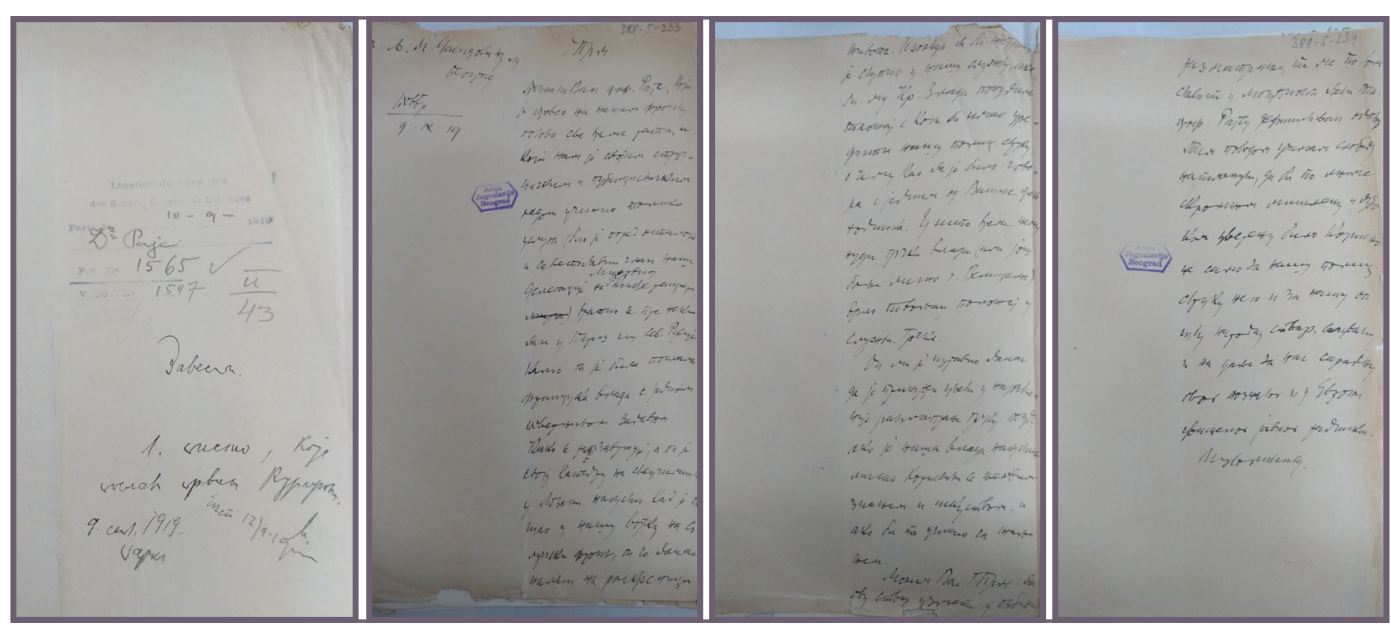




\section{APPENDIX B}

The Reiss's letter to King Aleksandar Karađorđević, March 22, 1929

Majesté,

Je lis dans les journaux que Votre Ministère de l'intérieur s'occupe à élaborer une nouvelle loi organique de la Police. A cette occasion je me permets de Vous dire que, en 1922 et sur la demande du Ministre de l'Intérieur d'alors, Monsieur Pribitchevitch, j'avais fait un projet de loi de la police qui fut le résumé des expériences et de ce que j'avais vu pendant ma carrière. Naturellement le Ministre voulant à tout-prix anéantir celui qui avait tout donné à la Nation serbe, a fait à ce projet un enterrement de première classe, mais d'autres pays me l'ont demandé ensuite. Et, malgré tous leurs efforts, ceux qui, au Ministère de l'intérieur voulaient ma mort professionnelle et scientifique n'ont pas réussi. Encore aujourd'hui mes livres font autorité dans le monde de la Police, en dehors des milieux policiers serbes, et aujourd'hui encore ils sont traduits, même en chinois.

Je n'ai aucune illusion sur ce que les gens de la police, maintenant que Vous avez ordonné de doter ce rouage important de la vie publique d'un nouveau statut allaient reprendre mon ancien travail. Mais Vous, Majesté, Vous m'avez dit aux moments difficiles de la guerre „Je compte sur vous pour m'aider à doter le pays serbe d'une bonne police". M'autorisant de cela, je Vous prie de Vous faire remettre ce projet et de le lire. Vous le trouverez certainement digne d'être pris en considération. Il est bien possible que, au Ministère, on l'ait fait disparaître, mais je possède l'original et je vous en ferai volontiers une copie.

Ne croyez pas, Majesté, que je vous écris tout cela pour me mettre en avant ou pour gagner des décorations et des* récompenses. Après la guerre les gouvernants du pays ne m'en ont jamais donné et je m'en passe encore très bien aujourd'hui. Mais, j'ai sacrifié tout ce qu'un homme peut sacrifier à Votre pays que j'aime comme le mien propre, et je voudrais que tout de même la force que je fus, ne soit pas entièrement perdue pour Votre Patrie par la jalousie de quelques-uns. De plus, j'ose croire que Vous avez bien senti l'affection et l'amitié sincères que je Vous porte, et je voudrais aider mon grand ami royal dans sa tâche difficile, mais si noble.

Excusez, Majesté, ma franchis(s)e et n'y voyez qu'une nouvelle preuve de dévouement affectueux de Votre vieux

R. A. Reiss 


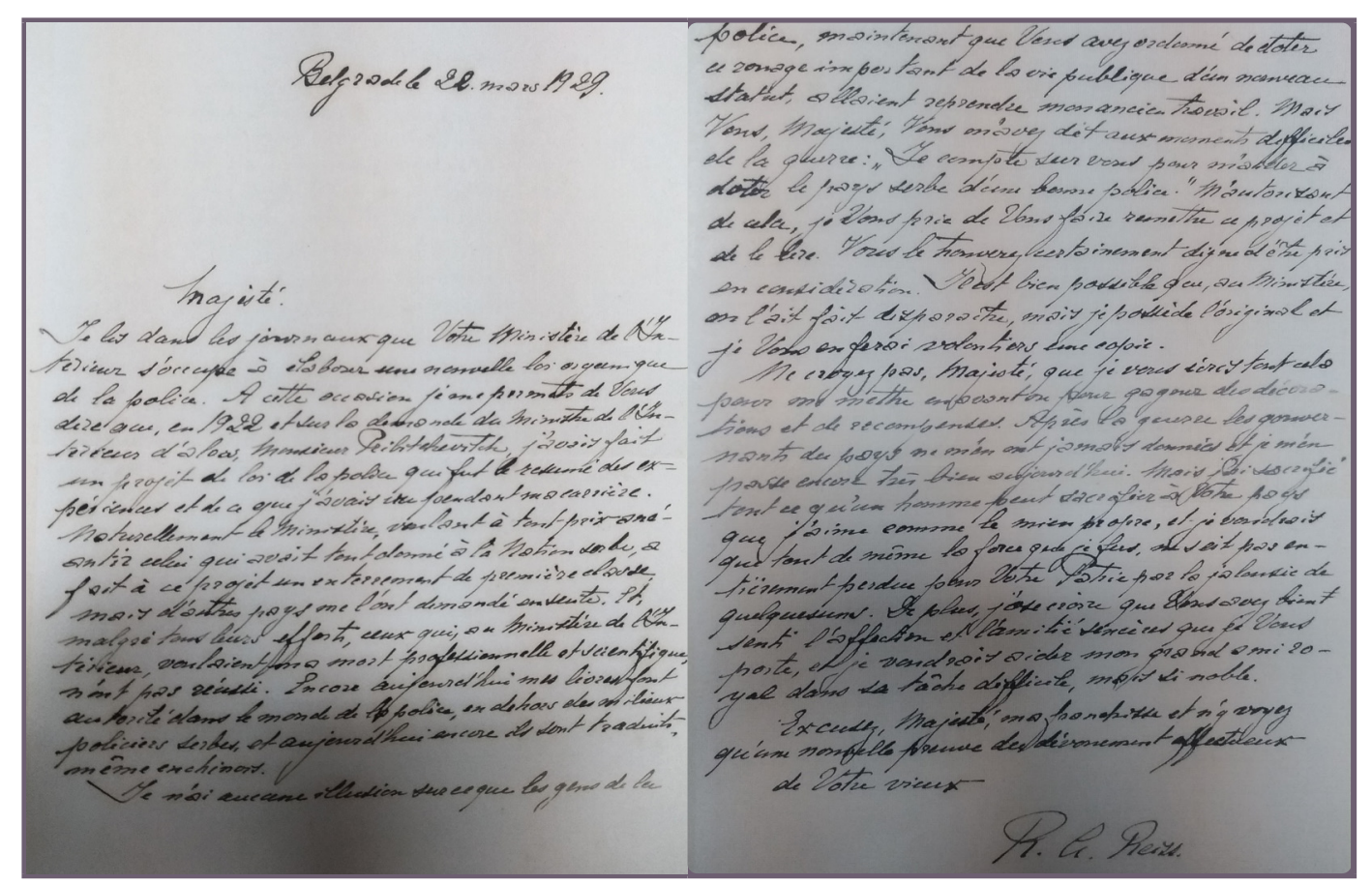

